\title{
Molecular Phylogeny Inferred from 18S rRNA Gene Sequences of Nematodes Associated with Cernuella virgata, a Pest Snail in Australia
}

\author{
Aisuo Wang ${ }^{1,2}$, Gavin Ash ${ }^{2,3^{*}}$, Mike Hodda ${ }^{3,4}$ and Farzad G. Jahromi ${ }^{5}$ \\ ${ }^{1}$ NSW Department of Primary Industries, Wagga Wagga Agricultural Institute, PMB, Wagga Wagga NSW 2650, Australia \\ ${ }^{2}$ Graham Centre for Agricultural Innovation, Locked bag 588, Wagga Wagga NSW 2678, Australia \\ ${ }^{3}$ School of Agricultural and Wine Sciences, Charles Sturt University, Wagga Wagga NSW 2678, Australia \\ ${ }^{4}$ CSIRO Entomology, GPO Box 1700 Canberra ACT 2601 Australia \\ ${ }^{5}$ Department of the Environment, Water, Heritage and the Arts, GPO Box 787 Canberra ACT 2601 Australia.
}

*Corresponding author: Gavin Ash, Graham Centre for Agricultural Innovation, Locked bag 588, Wagga Wagga NSW 2678, Australia, Tel: (+61) 02 6933 2765; Fax: (+61) 026933 2765; E-mail: gash@csu.edu.au

Rec date: Mar 01, 2015, Acc date: Mar 23, 2015, Pub date: Mar 31, 2015

Copyright: @ 2015 Ash G, et al. This is an open-access article distributed under the terms of the Creative Commons Attribution License, which permits unrestricted use, distribution, and reproduction in any medium, provided the original author and source are credited.

\begin{abstract}
Pest snails are economically important pests of the grain industry. Nematode based bioagent appears to be a hope for controlling pest snails in an environment friendly way. Based on the dataset of 18S rRNA gene sequences, we propose a molecular phylogeny of nematodes baited with Cernuella virgata in soils collected from southern states of Australia. A total of 12 species (representing eight genera of nematodes) were identified and the inferred phylogenetic trees (Neighbor-Joining and Minium Evolution) placed them within three (I, IV and VII) out of the seven clades, indicating the possibility of multiple origins of snail parasitism. In Clade I and Clade VII, nematodes associated with Cernuella virgata formed sister group relationships with some slug - parasitic nematodes. We assume that snail - parasitic nematodes and slug - parasitic nematodes might share common ancestors in their evolutionary histories.
\end{abstract}

Keywords: Phylogeny; 18S rRNA; Diplogasterida; Panagrolaimida; Rhabditida; Nematode, Cernuella virgata

\section{Introduction}

Nematode is one of the most abundant and diverse phylum in the animal kingdom [1]. Due to the lack of objective criteria for assessing homology of morphological characters regarding many nematodes, the systematics of this phylum has been contentious [2]. With the rapid development of molecular phylogeny, the evolutionary history of Nematoda was reassessed and new phylogenetic framework was pointed out [3-5]. Nevertheless, little is known about the phylogeny of nematodes associated with terrestrial gastropods, which are economically important invertebrates.

Ross et al. [2] reported the molecular phylogeny of slug-parasitic nematodes based on $18 \mathrm{~S}$ rRNA gene sequences. A total of eight slug parasitic nematode species (Agfa flexilis, Alloionema appendiculatum, Angiostoma limacis, Angiostoma dentifera, Cosmocercoides dukae, Mermithid sp., Phasmarhabditis Hermaphrodita and Phasmarhabditis neopapillosa) from six families (Agfidae, Alloionematidae, Angiostomatidae, Cosmocercidae, Mermithidae and Rhabditidae) were included in their study. The resulting phylogenetic trees placed eight species within four (I, III, IV and V) out of the five clades of Nematoda, indicating multiple origins of slug parasitism. Five out of the eight nematode species were clustered within Clade V, forming a monophyletic group covering two families (Agfidae, Angiostomatidae) and one genus (Phasmarhabditis). By considering the morphological diversity among these families, they stated that rapid evolution had occurred during the evolutionary history of slug - parasitic nematodes.
While the phylogeny of slug - parasitic nematodes was studied, the phylogeny of snail - parasitic nematodes remains unclear. One of the reasons is that few scientific data are available regarding the snail parasitic nematodes around the world. Our understanding for the snail/nematode associations is mostly based on surveys conducted by Mengert [6] in Germany, Morand [7] in France, Gleich et al. [8] in USA and Charwat and Davies [9] in Australia. Currently the confirmed snail - parasitic nematodes is quite limited (e.g. Angiostoma aspersae (Angiostomatidae), Phasmarhabditis hermaphroditaI (Rhabditidae) and Nemhelix bakeri (Cosmocercidae) $[10,11]$.

Terrestrial snails play a big role in agriculture and other industries. For examples, four introduced species of Mediterranean snails [Cernuella virgata (Da Costa), Theba pisana (Müller), Cochicella acuta (Müller) and Cochicella barbara (Linnaeus)], cause serious damage to the grain industry in Australia each year [12]. To control these pest snails efficiently and environment friendly, nematode - based biological control method was regarded as a priority among other options [9].

Effective use of nematodes requires knowledge of their relationships. Understanding the diversity of nematodes that are parasitic to terrestrial snails (especially for pest snails) and resolving the phylogeny of these nematodes will be useful to the development of nematode - based bioagent against pest snails.

In present study, we conducted a survey in southern Australia to screen nematode species with potentials as parasites of $C$. virgata. We also aim to solve the phylogenetic relationships of these nematode isolates using data from $18 \mathrm{~S}$ rRNA gene sequences. 
Citation: Wang A, Ash G, Hodda M, Jahromi FG (2015) Molecular Phylogeny Inferred from 18S rRNA Gene Sequences of Nematodes Associated with Cernuella virgata, a Pest Snail in Australia. J Phylogen Evolution Biol 3: 148. doi:10.4172/2329-9002.1000148

Page 2 of 10

\section{Materials and Methods}

\section{Soil sampling and nematode isolation}

Samples were collected from 27 locations in South Australia, Victoria and New South Wales in Australia between August 2007 and September 2008 (Table 1). Sites were chosen based on accessibility and habitats. At each site, five to eight subsamples were taken with at least a two meters distance between them. Each subsample was obtained using a hand trowel from the top soil (10-15 cm deep). Approximately $0.5 \mathrm{~kg}$ soil was taken from each spot and was placed in separate polyethylene bag to minimize dehydration. Soil samples were stored in an ice box while being transported to the laboratory. Nematodes were isolated from each sample by baiting with nematode-free snails $(C$. virgata) as reported by Charwat and Davies [9], then placed in water for 24 hours to release nematodes.

\begin{tabular}{|c|c|c|c|c|c|c|}
\hline Order & Family & $\begin{array}{l}\text { Closest match in } \\
\text { GENBANK }\end{array}$ & $\begin{array}{l}\text { GENBANK } \\
\text { accession } \\
\text { numbers }\end{array}$ & Collecting site & Similarity (\%) & Isolate number(s) \\
\hline \multirow[t]{13}{*}{ Diplogasterida } & Neodiplogasteridae & $\begin{array}{l}\text { Pristionchus americanus } \\
\text { isolate } 1373\end{array}$ & FJ040445 & Portland, Western Victoria & 97 & 4211 \\
\hline & & & & Mt Gambier, South Australia & 98 & 4611 \\
\hline & & & & Naracoorte, South Australia & 97 & 4711 \\
\hline & & & & Myponga, South Australia & 98 & 4712 \\
\hline & & & & Waikerie, South Australia & 98 & 5011 \\
\hline & & $\begin{array}{ll}\text { Pristionchus } & \text { Iheritieri } \\
\text { isolate ED2088 }\end{array}$ & AF430477 & $\begin{array}{l}\text { Cooma, Snowy Mountains } \\
\text { NSW }\end{array}$ & 91 & 3923 \\
\hline & & $\begin{array}{l}\text { Pristionchus } \\
\text { strain PS312 }\end{array}$ & AF083010 & Henty, Riverina NSW & 94,94 & 2921, 2923 \\
\hline & & & & Culcaim, Riverina NSW & 95 & 3012 \\
\hline & & & & Kiandra, Snowy Mtns NSW & $95,95,95$ & $3811,3812,3813$ \\
\hline & & & & $\begin{array}{l}\text { Adaminaby, Snowy Mtns } \\
\text { NSW }\end{array}$ & $95,95,95$ & $3814,3815,3816$ \\
\hline & & & & Heywood, Western Victoria & 94 & 4013 \\
\hline & & $\begin{array}{l}\text { Mononchoides striatus } \\
\text { strain MonEStr }\end{array}$ & AY593924 & $\begin{array}{l}\text { Adaminaby, Snowy Mtns } \\
\text { NSW }\end{array}$ & $90,91,91,91$ & $\begin{array}{l}3912,3826, \quad 3914, \\
3915\end{array}$ \\
\hline & & & & Cooma, Snowy Mtns NSW & 90,96 & 3922,3926 \\
\hline \multirow[t]{3}{*}{ Panagrolaimida } & Cephalobidae & $\begin{array}{l}\text { Acrobeloides } \\
\text { bodenheimeri } \quad \text { strain } \\
\text { PS1158 }\end{array}$ & AF202159 & $\begin{array}{l}\text { Yorketown, Yorke Peninsula } \\
\text { SA }\end{array}$ & 97 & 5512 \\
\hline & & $\begin{array}{l}\text { Acrobeloides } \\
\text { strain DWF1107 }\end{array}$ & EU543174 & Currawarna, Riverina NSW & 96,97 & 1015,0823 \\
\hline & & $\begin{array}{l}\text { Cephalobus persegnis } \\
\text { isolate CephPer1 }\end{array}$ & AY284662 & $\begin{array}{l}\text { Warooka, Yorke Peninsula } \\
\text { SA }\end{array}$ & 96 & 5211 \\
\hline \multirow[t]{7}{*}{ Rhabditida } & Mesorhabditidae & $\begin{array}{lr}\text { Mesorhabditis } & \mathrm{sp} . \\
\mathrm{JH}-2004 & \text { isolate MRhaSp2 }\end{array}$ & AY284660 & $\begin{array}{l}\text { Gobbagombalin, Riverina } \\
\text { NSW }\end{array}$ & 96 & 212 \\
\hline & & & & $\begin{array}{l}\text { Miniaton, Yorke Peninsula } \\
\text { SA }\end{array}$ & 98 & 5112 \\
\hline & Rhabditidae & $\begin{array}{l}\text { Oscheius tipulae strain } \\
\text { CEW1 }\end{array}$ & EU196009 & Malebo, Riverina NSW & 98 & 431 \\
\hline & & & & Cootamundra, Riverina NSW & 97 & 2611 \\
\hline & & & & Culcaim, Riverina NSW & 96,97 & 3013,3021 \\
\hline & & & & Uranquinty, Riverina NSW & 97 & 3111 \\
\hline & & & & Griffith, Riverina NSW & $97,98,99$ & $3312,3323,3312$ \\
\hline
\end{tabular}




\begin{tabular}{|l|l|l|l|l|l|l|}
\hline & & & Leeton, Riverina NSW & $95,97,98,98$ & $\begin{array}{l}3524, \quad 3522, \quad 3521, \\
3523\end{array}$ \\
\hline & & & & Narradera, Riverina NSW & 97,97 & 3621,3623 \\
\hline & & Oscheius sp. PS1131 & OBU81587 & The Rock, Riverina NSW & 99 & 2822 \\
\hline & & Rhabditis sp. DF5059 & EU196007 & $\begin{array}{l}\text { Adaminaby, Snowy Mtns } \\
\text { NSW }\end{array}$ & 98 & 2911 \\
\hline & & & & Port Fairy Western Victoria & 98 & 3821 \\
\hline Rhabditida & Heterorhabditidae & $\begin{array}{l}\text { Heterorhabditis } \\
\text { bacteriophora }\end{array}$ & AF036593 & Euberta, Riverina NSW & 91 & 4411 \\
\hline
\end{tabular}

Table 1: Nematode isolates from this study.

\section{DNA extraction}

Nematode DNA was extracted from individual nematodes using a modification of the protocol described by Floyd et al. [13]. In brief, individual nematodes (adults or larvae) were transferred to a $0.2 \mathrm{ml}$ Eppendorf tube containing $20 \mu \mathrm{l}$ of $0.25 \mathrm{M} \mathrm{NaOH}$, incubated at $25^{\circ} \mathrm{C}$ for 3-5 hours, then heated at $95^{\circ} \mathrm{C}$ in a Dri-Block heater (DB-2A: Techne Inc., Duxford UK) for $3 \mathrm{~min}$. The resulting lysate was neutralized with $4 \mu \mathrm{l}(1 \mathrm{M}) \mathrm{HCl}$ and $10 \mu \mathrm{l} 0.5 \mathrm{M}$ Tris- $\mathrm{HCl}$ (buffered at $\mathrm{pH} 8.0$ ), then heated for $3 \mathrm{~min}$ at $95^{\circ} \mathrm{C}$, followed by addition of $5 \mu \mathrm{l} 2 \%$ Triton X-100. The final extract was stored at $-20^{\circ} \mathrm{C}$ for later use.

\section{Choice of DNA markers}

Both nuclear and mitochondrial genes (18S rRNA, $28 \mathrm{~S}$ rRNA, Cytochrome C oxidase I and $16 \mathrm{~S}$ rRNA) were considered for study. $18 \mathrm{~S}$ rRNA gene was chosen for three reasons. First, in pilot trials, PCR amplifications were obtained more reliably from 18S rRNA gene than from other candidate genes. Second, a large dataset of sequences was available on GENBANK or NemATOL for many species of nematodes across a range of taxonomic groups [3,13-15]. Third, this gene contains both conserved stem and highly divergent loop regions, making it suitable for taxonomic differentiation [13].

\section{DNA amplification and sequencing}

PCRs were conducted in $0.2 \mathrm{ml}$ thin-walled Eppendorf PCR tubes. For each extract, $25 \mu \mathrm{l}$ of reaction solution was prepared, containing $3 \mu \mathrm{l}$ extracted DNA, $5 \mu \mathrm{l} 5 \mathrm{x}$ colourless GoTaq reaction buffer, $2 \mu \mathrm{l} 25$ $\mathrm{mM} \mathrm{MgCl} 2,2.5 \mu \mathrm{l} 2 \mathrm{mM}$ deoxyribonucleotide triphosphates (dNTPs), 0.04 units GoTaq DNA Polymerase (Promega), $6.5 \mu \mathrm{lddH} 2 \mathrm{O}$, and 3 $\mu \mathrm{l} \quad 2.5 \mu \mathrm{M}$ each of the two primers: SSU18A (AAAGATTAAGCCATGCATG) and SSU26R (CATTCTTGGCAAATGCTTTCG) [3]. The thermocycling was performed on a PC -960C cooled thermal cycler (Corbett Research), with parameters of $94^{\circ} \mathrm{C}$ for $5 \mathrm{~min}, 35$ cycles of $94^{\circ} \mathrm{C}$ for $45 \mathrm{~s}, 56^{\circ} \mathrm{C}$ for $45 \mathrm{~s}$ and $72^{\circ} \mathrm{C}$ for $1.5 \mathrm{~min}$, and a final extension of $72^{\circ} \mathrm{C}$ for $10 \mathrm{~min}$, followed by a holding temperature of $15^{\circ} \mathrm{C}$. The $3 \mu$ PCR products were visualized on agarose gels stained with ethidium bromide.

Sequences of purified PCR products were obtained from both directions using the same primer pairs for PCR. Sequencing reactions were performed with the Applied Biosystems BigDyeTM Terminator Ready Reaction Kit (Version 3.1) (Applied Biosystems Ltd). Final capillary separation was carried out at Australian Genome Research Facility Ltd (AGRF), where the samples were analysed using an AB3730xl (Applied Biosystems).

\section{Phylogenetic analysis}

Sequence traces were checked for their quality using the Trace Editor of MEGA v 4.0. [16]. A total of 47 DNA sequences were screened for their statistical similarities (positive matrix scores) with $18 \mathrm{~S}$ rRNA gene sequences of identified nematodes in GENBANK by performing blast search [17]. Among the 12 identified groups, a single DNA sample was selected from each group to align with other 51 nematode 18S rRNA gene sequences that were downloaded from GenBank (Table 2). These additional nematode taxa were chosen based on their taxonomy positions and their relationships with terrestrial molluscs and other invertebrates. The alignments of these DNA sequences were conducted with Clustal $\mathrm{X}$ using the default parameters for gap opening and gap extension penalties [18]. A final 543 aligned characters were applied in the phylogenetic analysis. Neighbour-Joining (NJ) and Minimum Evolution (ME) trees were constructed with MEGA v 4.0 [16] using Kimura 2- parameter model. Gaps were treated as missing data in the analysis. The outgroup of Tylenchus arcuatus (Chromadorea, Nematoda) (Accession number: EU306349) was used to root the trees and for character polarization. Bootstrap support was calculated for all analyses using 1000 replicates.

\begin{tabular}{|l|l|l|l|l|}
\hline Counting & $\begin{array}{l}\text { Taxon (species name and strain and identification } \\
\text { code) }\end{array}$ & Source material & Trophic ecology & GENBANK \\
\hline 1 & Acrobeles complexus & GenBank & Bacteriovore & AY284671 \\
\hline 2 & Acrobeloides bodenheimeri (5512) & Current study & Bacteriovore & TBA \\
\hline 3 & Acrobeloides butschlii (0823) & Current study & Bacteriovore & TBA \\
\hline
\end{tabular}


Citation: Wang A, Ash G, Hodda M, Jahromi FG (2015) Molecular Phylogeny Inferred from 18S rRNA Gene Sequences of Nematodes Associated with Cernuella virgata, a Pest Snail in Australia. J Phylogen Evolution Biol 3: 148. doi:10.4172/2329-9002.1000148

Page 4 of 10

\begin{tabular}{|c|c|c|c|c|}
\hline 4 & Agfa flexilis & GenBank & Invertebrate parasite & EU573704 \\
\hline 5 & Alloionema appendiculatum & GenBank & Invertebrate parasite & EU573707. \\
\hline 6 & Angiostoma dentifera & GenBank & Invertebrate parasite & FJ516752 \\
\hline 7 & Angiostoma limacis & GenBank & Invertebrate parasite & EU573705 \\
\hline 8 & Bathyodontus cylindricus & GenBank & Bacteriovore & AY552964 \\
\hline 9 & Brumptaemilius justini & GenBank & Invertebrate parasite & AF036589 \\
\hline 10 & Caenorhabditis dropophilae & GenBank & Bacteriovore & AF083025 \\
\hline 11 & Caenorhabditis elegans & GenBank & Bacteriovore & AY268117 \\
\hline 12 & Caenorhabditis japonica & GenBank & Bacteriovore & AY602182 \\
\hline 13 & Caenorhabditis plicata & GenBank & Bacteriovore & AY602178 \\
\hline 14 & Cephaloboides sp. & GenBank & Bacteriovore & AF083027 \\
\hline 15 & Cephalobus persegnis (5211) & Current study & Bacteriovore & TBA \\
\hline 16 & Cosmocercoides dukae & GenBank & Invertebrate parasite & FJ516753 \\
\hline 17 & Cruznema tripartitum & GenBank & Bacteriovore & CTU73449 \\
\hline 18 & Cuticularia sp. & GenBank & Bacteriovore & CSU81583 \\
\hline 19 & Diploscapter coronatus & GenBank & Bacteriovore & AY593921 \\
\hline 20 & Heterorhabditis bacteriophora & GenBank & Entomopathogen & FJ040428 \\
\hline 21 & Heterorhabditis bacteriophora (0512) & Current study & Bacteriovore & TBA \\
\hline 22 & Heterorhabditis hepialus & GenBank & Entomopathogen & AF083004 \\
\hline 23 & Isomermis lairdi & GenBank & Invertebrate parasite & FN400900 \\
\hline 24 & Mermis nigrescens & GenBank & Invertebrate parasite & AF036641 \\
\hline 25 & Mermis sp. & GenBank & Invertebrate parasite & FJ973464 \\
\hline 26 & Mermithid sp. & GenBank & Invertebrate parasite & AY284743 \\
\hline 27 & Mermithidae & GenBank & Invertebrate parasite & FJ982324 \\
\hline 28 & Mermithidae & GenBank & Invertebrate parasite & FJ040480 \\
\hline 29 & Mesorhabditis sp. (5112) & Current study & Bacteriovore & TBA \\
\hline 30 & Mononchoides striatus & GenBank & Bacteriovore & AY593924 \\
\hline 31 & Mononchoides striatus (3912) & Current study & Bacteriovore & TBA \\
\hline 32 & Nemhelix bakeri & GenBank & Invertebrate parasite & DQ118537 \\
\hline 33 & Oscheius dolichura & GenBank & Bacteriovore & EU196010 \\
\hline 34 & Oscheius insectivora & GenBank & Bacteriovore & AF083019 \\
\hline 35 & Oscheius sp. & GenBank & Bacteriovore & OBU81587 \\
\hline 36 & Oscheius sp. (3623) & Current study & Bacteriovore & TBA \\
\hline 37 & Oscheius tipulae & GenBank & Bacteriovore & EU196009 \\
\hline 38 & Oscheius tipulae (3524) & Current study & Bacteriovore & TBA \\
\hline 39 & Panagrellus redivivus & GenBank & Bacteriovore & AF083007 \\
\hline
\end{tabular}


Citation: Wang A, Ash G, Hodda M, Jahromi FG (2015) Molecular Phylogeny Inferred from 18S rRNA Gene Sequences of Nematodes Associated with Cernuella virgata, a Pest Snail in Australia. J Phylogen Evolution Biol 3: 148. doi:10.4172/2329-9002.1000148

Page 5 of 10

\begin{tabular}{|c|c|c|c|c|}
\hline 40 & Panagrobelus stammeri & GenBank & Bacteriovore & AF202153 \\
\hline 41 & Panagrolaimus sp. & GenBank & Bacteriovore & U81579.1 \\
\hline 42 & Pellioditis marina & GenBank & Bacteriovore & AF083021 \\
\hline 43 & Pellioditis mediterranea & GenBank & Bacteriovore & AF083020 \\
\hline 44 & Pellioditis sp. & GenBank & Bacteriovore & EU196011 \\
\hline 45 & Pellioditis typica & GenBank & Bacteriovore & PTU13933 \\
\hline 46 & Phasmarhabditis hermaphrodita & GenBank & Invertebrate parasite & FJ516755 \\
\hline 47 & Phasmarhabditis neopapillosa & GenBank & Invertebrate parasite & FJ516754 \\
\hline 48 & Plectus acuminatus & GenBank & Bacteriovore & AF037628 \\
\hline 49 & Prismatolaimus intermedius & GenBank & Bacteriovore & AY284729 \\
\hline 50 & Pristionchus americanus (4611) & Current study & Bacteriovore & TBA \\
\hline 51 & Pristionchus Iheritieri (3923) & Current study & Bacteriovore & TBA \\
\hline 52 & Pristionchus pacificus (3812) & Current study & Bacteriovore & TBA \\
\hline 53 & Rhabditella axei & GenBank & Bacteriovore & RAU13934 \\
\hline 54 & Rhabditis colombiana & GenBank & Bacteriovore & AY751546 \\
\hline 55 & Rhabditis myriophila & GenBank & Bacteriovore & RMU81588 \\
\hline 56 & Rhabditis sp. (4411) & Current study & Bacteriovore & TBA \\
\hline 57 & Rhabditophanes sp. & GenBank & Bacteriovore & AF202151 \\
\hline 58 & Steinernema affine & GenBank & Entomopathogen & FJ040425 \\
\hline 59 & Steinernema carpocapsae - & GenBank & Entomopathogen & AF036604 \\
\hline 60 & Steinernema glaseri & GenBank & Entomopathogen & FJ040422 \\
\hline 61 & Teratocephalus lirellus & GenBank & Bacteriovore & AF036607 \\
\hline 62 & Turbatrix aceti & GenBank & Bacteriovore & AF202165 \\
\hline 63 & Tylenchus arcuatus & GenBank & Plant parasite & EU306349 \\
\hline 64 & Zeldia punctata & GenBank & Bacteriovore & ZPU61760 \\
\hline
\end{tabular}

Table 2: Taxa used in present study for NJ and ME analyses.

\section{Results}

\section{Nematode isolates}

A total of 47 nematode isolates were obtained by baiting C. virgata in soils collected from southern states of Australia. The corresponding $18 \mathrm{~S}$ rRNA gene sequences of these nematode isolates matched 12 nematode species listed in the GENBANK database (Table 1). Among of them, the most common species was Oscheius tipulae (14 isolates from 7 sites), followed by Pristionchus pacificus (10 isolates from 5 sites), Mononchoides striatus (6 isolates from 2 close sites) and Pristionchus americanus (5 isolates from 5 sites). According to the currently accepted classification of nematodes [19], the species fell into eight genera (Pristionchus, Mononchoides, Acrobeloides, Cephalobus, Mesorhabditis, Oscheius, Rhabditis, Heterorhabditis), and three orders (Diplogasterida, Rhabditida and Panagrolaimida) (Table 1).

\section{Phylogenetic analysis}

Phylogenetic trees (Neighbour Joining and Minimum Evolution) were constructed via phylogenetic analyses of $18 \mathrm{~S}$ rRNA gene dataset arising from 64 taxa described above. In these phylogenetic trees, seven Clades were revealed and three out of them (clade I, IV and VII) contained nematodes associated with $C$. virgata (Figure 1, Figure 2). 
Citation: Wang A, Ash G, Hodda M, Jahromi FG (2015) Molecular Phylogeny Inferred from 18S rRNA Gene Sequences of Nematodes Associated with Cernuella virgata, a Pest Snail in Australia. J Phylogen Evolution Biol 3: 148. doi:10.4172/2329-9002.1000148
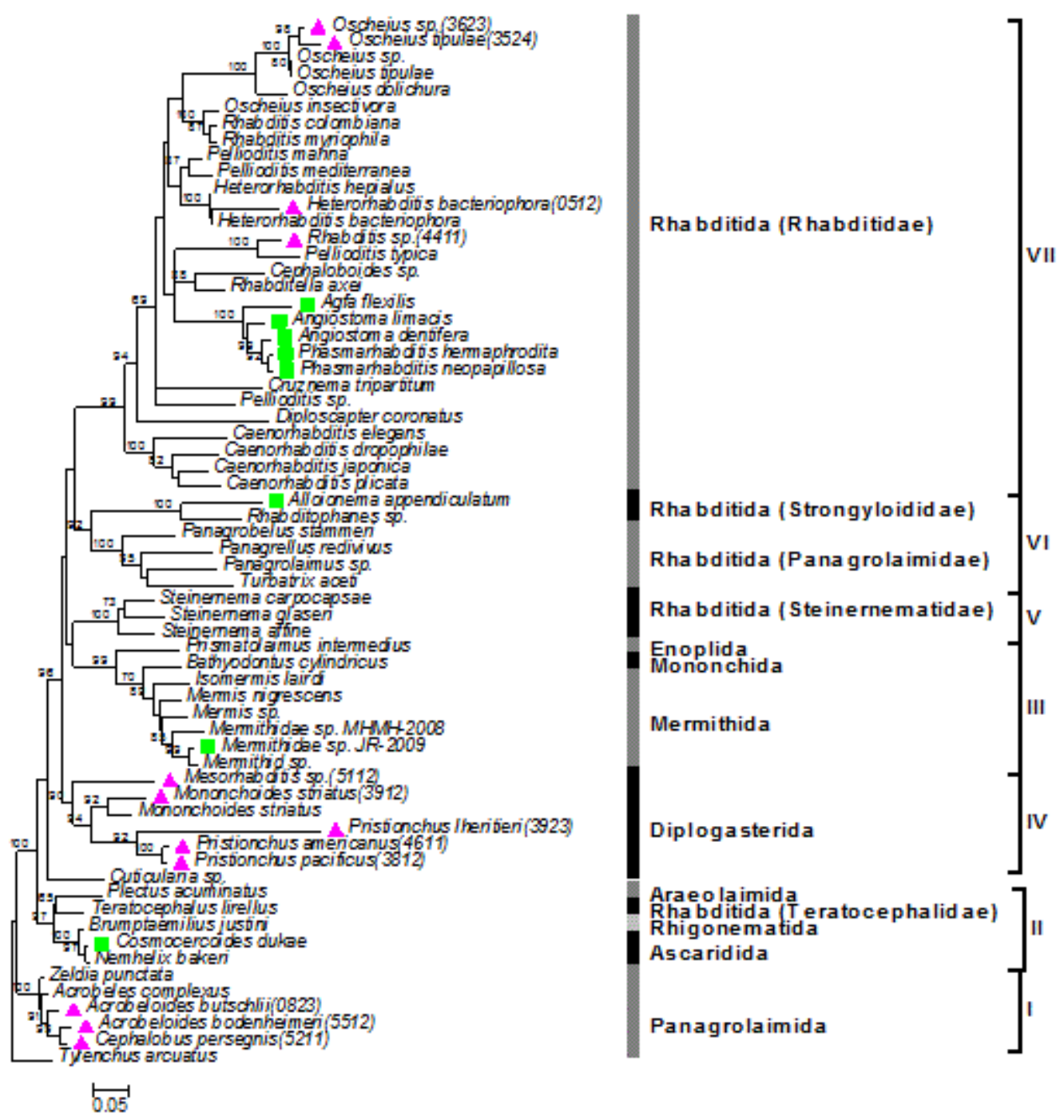

Figure 1: Minimum Evolution phylogenetic tree of $6418 \mathrm{~S}$ rRNA gene sequences showing the major seven Clades of nematodes, three of which contain nematodes which are potentially parasitic to $C$. virgata. Bootstrap support was calculated using Minimum Evolution method (1000 replicates each). Only values above 65\% are shown. Tylenchus arcuatus was used as the outgroup. Pink triangle: potential snail parasitic nematodes from current study; Green square: slug - parasitic nematodes.

Clade I: Three nematode isolations from the present study, Acrobeloides butschlii (0823), Acrobeloides bodenheimeri (5512) and Cephalobus persegnis (5211) were placed in Clade I (Panagrolaimida) in all topologies (Figure 1, Figure 2). Both $\mathrm{NJ}$ and ME trees depicted a sister-group relationship between these taxa and the other two members of Panagrolaimida (Acrobeles complexus and Zeldia punctata). This placement received very strong bootstrap support in both phylogenetic trees (100\%).

Clade IV: In both $\mathrm{NJ}$ and ME trees, four nematode species from current study, Mononchoides striatus (3912), Pristionchus americanus
(4611), Pristionchus Iheritieri (3923) and Pristionchus pacificus (3812), were included in this clade IV (Diplogasterida). Among of them, P. americanus (4611), P. Iheritieri (3923), and P. pacificus (3812) formed a monophyletic clade with strong bootstrap support (96\% in NJ tree and $92 \%$ in ME tree). This monophyletic clade is nested within the Clade IV and sister to Mononchoides striatus (3912) and Mononchoides striatus. This result received very strong bootstrap support (98\% in NJ tree and $94 \%$ in ME tree). 
Citation: Wang A, Ash G, Hodda M, Jahromi FG (2015) Molecular Phylogeny Inferred from 18S rRNA Gene Sequences of Nematodes Associated with Cernuella virgata, a Pest Snail in Australia. J Phylogen Evolution Biol 3: 148. doi:10.4172/2329-9002.1000148

Page 7 of 10

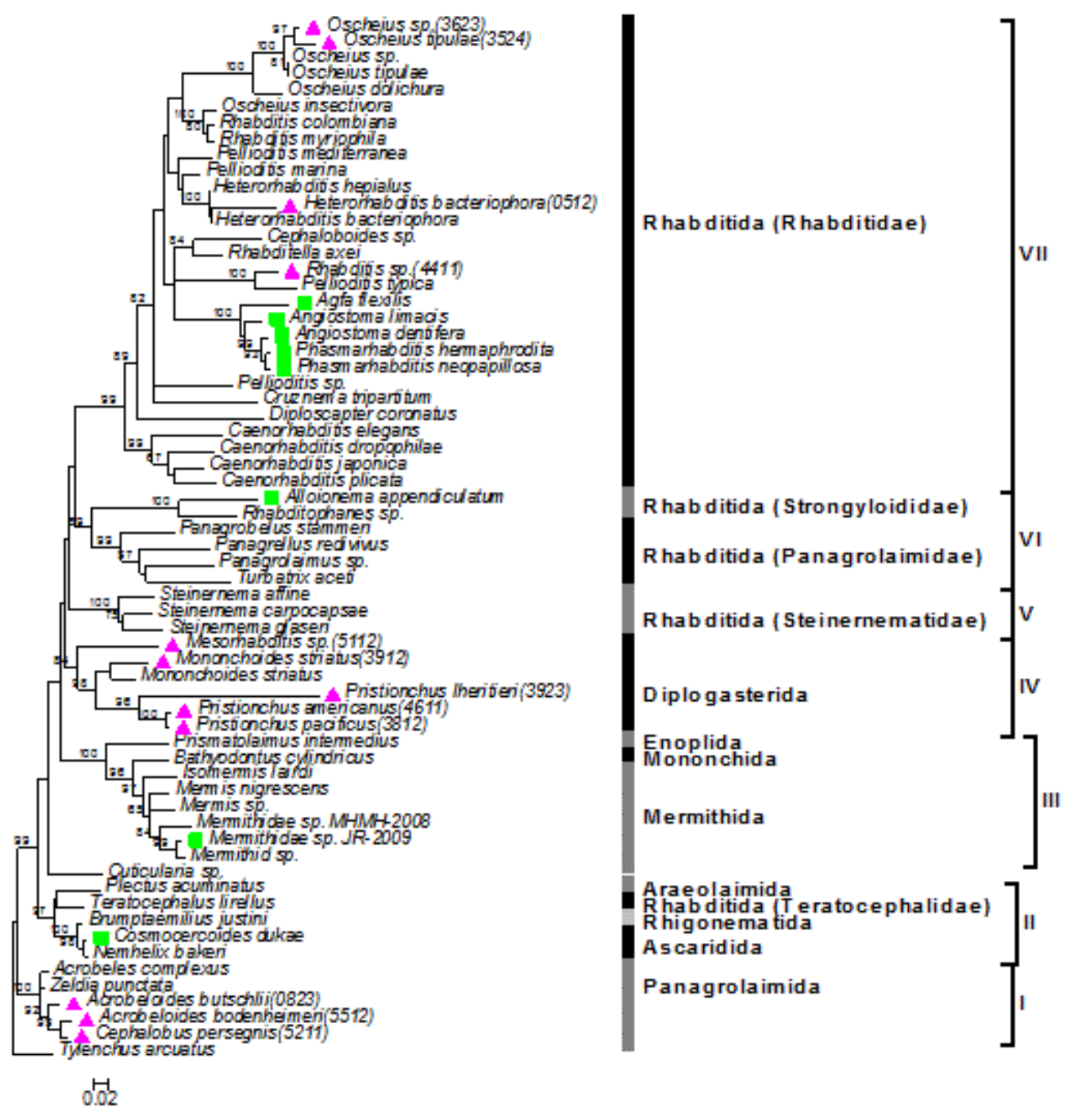

Figure 2: Neighbor: Joining (NJ) phylogenetic tree of $6418 \mathrm{~S}$ rRNA gene sequences showing the major seven Clades of nematodes, three of which contain nematodes which are potentially parasitic to $C$. virgata. Bootstrap support was calculated using Neighbor - Joining method (1000 replicates each). Only values above 65\% are shown. Tylenchus arcuatus was used as the outgroup. Pink triangle: potential snail parasitic nematodes from current study; Green square: slug - parasitic nematodes.

Clade VII: Four nematode isolations from the present study, Heterorhabditis bacteriophora (0512), Oscheius tipulae (3524), Oscheius sp. (3623) and Rhabditis sp. (4411), were placed in this clade (Rhabditida), the largest clade across all phylogenetic analyses. Among of them, Oscheius tipulae (3524) and Oscheius sp. (3623) formed a well-supported clade with three other members of Oscheius (Oscheius sp., Oscheius tipulae and Oscheius dolichura) (100\% in both NJ and ME trees). Heterorhabditis bacteriophora (0512) was found to cluster with Heterorhabditis bacteriophora under weak bootstrap support. They were sister to Heterorhabditis hepialus and formed a clade with $100 \%$ bootstrap support across both phylogenetic trees. Instead of being clustered with other members of Rhabditis, Rhabditis sp. (4411) was found to cluster with Pellioditis typica in all phylogenetic trees with strong bootstrap support (100\%). Both NJ and ME trees also depicted a sister - group relationship between these two species and other five slug - parasites (Agfa flexilis, Angiostoma limacis, Angiostoma dentifera, Phasmarhabditis Hermaphrodita and Phasmarhabditis neopapillosa).

\section{Discussion}

The present study revealed a total of 12 nematode species that are potentially associated with $C$. virgata, a pest snail in Australia. Phylogenetic analyses of $18 \mathrm{~S}$ rRNA gene sequences placed these nematode species into three large groups: Panagrolaimida, Diplogasterida and Rhabditida (Figure 1, Figure 2), indicating the possible multiple origins of snail parasitism, which is similar to the findings of slug - parasitic nematodes [2]. 


\section{The relationship of potential snail parasites in relation to other nematodes in clade I, IV and VII}

Clade I: In present study, phylogenetic analyses recovered a monophyletic clade I (Panagrolaimida), which includes Acrobeloides bodenheimeri (5512), Acrobeloides butschlii (0823), Cephalobus persegnis (5211), and two other members of Cephalobidae: Zeldia punclata and Acrobeles complexus. This finding is in consistent with the results of Nadler et al. [20], who confirmed the monophyly of cephlobids at superfamily level based on phylogenetic analyses of ribosomal (LSU) sequences data.

Cephalobidae include a diverse array of species ranging from soil dwelling microbivores to parasites of vertebrates and invertebrates [20]. The phylogeny of genera within Cephalobidae (such as Acrobeloides, Cephalobus, Chiloplacus, Eucephalobus and Pseudacrobeles) has been in controversy [20]. Molecular trees did not support traditional genera as natural group [20]. Similarly, morphological characters traditionally applied for distinguishing most genera (e.g. labial variations) were not regarded as diagnostic with the discovery of increasing new species [21]. Such a controversy was reflected in present study. Both $\mathrm{NJ}$ and ME trees did not support Acrobeloides and Cephalobus as monophyletic groups.

The NJ and ME trees also depicted a closely related relationship between Clade I and a group including the slug - parasite (Cosmocercoides dukae) and the snail - parasite (Nemhelix bakeri) (Figure 1, Figure 2), indicating the possibility of a common ancestor between these nematodes.

Clade IV: The monophyly of clade IV (Diplogastropoda), which includes Pristionchus Iheritieri (3923), Pristionchus americanus (4611), Pristionchus pacificus (3812), Mononchoides striatus (3912) and Mononchoides striatus, was resolved through both NJ and ME analyses in present study. Strong bootstrap support was observed for this clade in NJ (98\%) and ME (94\%) trees (Figure 1, Figure 2). This finding is in consistent with the results reported by Fürst von Lieven [22], who constructed a robust cladogram for Diplogastropoda based on morphological data (e.g. the variable structures of the buccal cavity and the function of the stomatal structures).

Traditionally Diplogastropoda was regarded as a sister taxa of Tylenchina [23] because the morphology of pharynx between these two groups is very similar. Data from molecular and ultrastructure, however, strongly object the Diplogasteridal Tylenchida clade [3,24]. The close phylogenetic relationship between Diplogastropoda and Tylenchina is not supported by our results. Neither the NJ analysis nor the ME analysis indicated that Diplogastropoda is a sister taxa of Tylenchina (Figure 1, Figure 2).

Surveys conducted by Mengert [6], Morand [7], Gleich et al. [8], Charwat and Davies [9] indicated that some species within the Diplogastropoda might associate with terrestrial molluscs parasitically, phoretically or necromenically. The present study supported their findings but was inconsistent with Ross et al. [2], who found no members of the Diplogasteridae were parasitic to slugs.

Clade VII: Being the largest clade recovered from the present study, Clade VII (Rhabiditidae) includes 12 genera (Agfa, Angiostoma, Caenorhabditis, Cephaloboides, Cruznema, Diploscapter, Heterorhabditis, Oscheius, Pellioditis, Phasmarhabditis, Rhabditella and Rhabditis). While the monophyly of this clade (Rhabditidae) was strongly supported (99\% in both NJ and ME trees), the monophyly of some genera within Rhabditidae was not fully supported. As described previously, four nematode isolates from present study, Oscheius tipulae (3524), Oscheius sp. (3623), Rhabditis sp. (4411) and Heterorhabditis bacteriophora (0512), were placed within this clade. Oscheius tipulae (3524) and Oscheius sp. (3623) were closely related with other members of Oscheius but separated from Oscheius insectivora; Rhabditis sp. (4411) was clustered with Pellioditis typica rather than with other members of Rhabditis. All these unexpected grouping indicate that additional data are needed to resolve the position of these genera.

Within the Clade VII, Rhabditis sp. (4411) formed a sister relationship with Agfa flexilis, Angiostoma limacis, Angiostoma dentifera, Phasmarhabditis Hermaphrodita and Phasmarhabditis neopapillosa. The latter five nematodes are all slug - parasites [2]. Such a connection strongly suggests the possibility that snail- parasitic nematodes might share a common ancestor with slug - parasitic nematodes.

The remaining nematode isolate, Mesorhabditis sp. (5112), was separated from other nematode isolates in both $\mathrm{NJ}$ and ME analyses (Figure 1, Figure 2). As a member of Mesorhabditidae, it was expected to cluster with other members of Rhabditida. However, it was actually sister to Clade IV (Diplogasterida) in all phylogenetic trees ( $84 \%$ in NJ and $90 \%$ in ME). Additional research is thus required to resolve the phylogenetic position of this taxon.

\section{Other phylogenetic finding in term of nematode phylogeny incurred from this study}

While recovering the phylogenetic positions of our 12 nematode isolates, the resulting $\mathrm{NJ}$ and $\mathrm{ME}$ trees also presented enlightenments on the phylogeny of other nematode taxa.

Mermithida are a group of insect - parasitic nematodes. They are usually associated with arthropods but were also found to be parasites of Molluscs [25]. Our analyses resolved the monophyly of Mermithda (89\% in ME tree and $97 \%$ in NJ tree). The phylogenetic trees also had moderate to strong support to the sister group relationship between Mermithida and Monochida (70\% in ME tree and $96 \%$ in NJ tree). These findings are in consistent with other author's results Megan et al. [1] and Ross et al. [2] but disagree with Stock and Hunt [26], who placed the Mermithidae as a sister group to the plant - parasitic Dorylaimids.

Another clade that was proved to be monophyletic is Sterinernematidae (100\% for both NJ and ME). Sterinernematidae is a family of entomopathogenic nematodes (EPN) [27]. It shares similar life history with the other family of entomopathogenic nematodes (Heterorhabditidae) (such as killing insects by realising symbiotically associated bacteria into the hemocoel of insects), but has distantly related phylogenetic relationship with Heterorhabditidae [28]. This situation was reflected in our phylogenetic analyses: the members of Heterorhabditidae (Heterorhabditis bacteriophora and Heterorhabditis hepialus) were placed in clade VII while the member of Sterinernematidae formed a separate clade (clade V) across both NJ and ME trees.

The inferred phylogenetic trees also showed that Sterinernematidae was more closely related to a clade including most Panagrolaimidae (free-living and insect associates). Both $\mathrm{NJ}$ and $\mathrm{ME}$ trees strongly supported the monophyly of Panagrolaimidae (100\% in ME and 99\% in NJ). These results are in consistent with the finding reported by Adam et al. [29]. 


\section{Are these nematodes really snail parasites?}

By using $C$. virgata as baiting material, we found that 12 nematodes species Acrobeloides butschlii (0823), Acrobeloides bodenheimeri (5512), Cephalobus persegnis (5211), Mononchoides striatus (3912), Pristionchus americanus (4611), Pristionchus Iheritieri (3923), Pristionchus pacificus (3812), Heterorhabditis bacteriophora (0512), Oscheius tipulae (3524), Oscheius sp. (3623), Rhabditis sp. (4411) and Mesorhabditis sp. (5112)] were potentially associated with $C$. virgata, a pest snail in Australia. Although it is hard to seek testable evidence to confirm this finding, the hypothesis of these nematodes (or some of them) as potential parasites of $C$. virgata is justified as below.

Reports about bacterivorous nematodes being developed as bioagent against pest slugs (e.g. P. hermaphrodita) have been published [30,31]. From the point of ecological view, all our nematodes isolates fall into the category of free-living bacterivorous nematodes (FLBN). The close relationship between some of our nematodes isolates with some slug parasites were also revealed by the phylogenetic analyses conducted in present study. In this respect, we could not deny the potentiality that bioagents against pest snails such as $C$. virgata can be developed from these nematode isolates.

All parasitic nematodes were originally evolved from free living nematodes [3]. Parasitism of plants and animals has evolved independently at least nine times in the history of the nematodes [14]. The adoption of parasitism in nematodes probably required either the adaptation of genes present in their free-living ancestors or horizontal gene transfer from bacteria and/or fungus in their environment [32-35]. Given the fact that our nematode isolates are bacterivirous, and have been isolated from the cadavers of pest snails ( $C$. virgata), it is likely that they could acquire "parasitism genes" from bacteria in their environment, and become parasites of pest snails at some stages of their life cycle.

Identification of some "parasitism genes" by examining the expression pattern of their $C$. elegans orthologs at certain stage of development (e.g. the third larval stage) would be useful in assessing the parasitism of nematodes $[32,36]$. Further pathogenicity tests are now underway to assess the biocontrol potential of these nematode isolates.

\section{Conclusion}

This study presents the molecular phylogeny of nematodes baited from the pest snail of $C$. virgata in Australia. Both $\mathrm{NJ}$ and ME trees constructed based on the dataset of $18 \mathrm{~S}$ rRNA gene sequences placed 12 nematode isolates into three out of seven Clades (I, IV and VII), suggesting the possibility of multiple origins of snail parasitism. In Clade I and Clade VII, nematodes associated with $C$. virgata formed sister group relationships with some slug - parasitic nematodes. We assume that snail - parasitic nematodes and slug - parasitic nematodes might share common ancestors in their evolutionary histories.

\section{Acknowledgements}

We are grateful for the help provided by AGRF in sequencing our DNA samples. The project was financially supported by the Grains Research and Development Corporation (GRDC).

\section{References}

1. Megen HV, Elsen SVD, Holterman M, Karssen G, Mooyman P, et al. (2009) A phylogenetic tree of nematodes based on about 1200 full-length small subunit ribosomal DNA sequences. Nematology 11: 927-950.

2. Ross JL, Ivanova ES, Spiridonov SE, Waeyenberge L, Moens M, et al. (2010) Molecular phylogeny of slug-parasitic nematodes inferred from $18 \mathrm{~S}$ rRNA gene sequences. See comment in PubMed Commons below Mol Phylogenet Evol 55: 738-743.

3. Blaxter ML, De Ley P, Garey JR, Liu LX, Scheldeman P, et al. (1998) A molecular evolutionary framework for the phylum Nematoda. See comment in PubMed Commons below Nature 392: 71-75.

4. Holterman M, Wurff A V D, Elsen S V D, Megen H V, Bongers T, et al. (2006) Phylum-wide analysis of SSU rDNA reveals deep phylogenetic relationships among nematodes and accelerated evolution toward crown clades. Mol Biol Evol 23: 1792- 1800.

5. Meldal BH, Debenham NJ, De Ley P, De Ley IT, Vanfleteren JR, et al. (2007) An improved molecular phylogeny of the Nematoda with special emphasis on marine taxa. See comment in PubMed Commons below Mol Phylogenet Evol 42: 622-636.

6. Mengert H (1953) Nematoden und Schneken. Zeitschrift f $\tilde{A}^{1 / 4} \mathrm{r}$ Morphologie und Ã-ekologie Tiere 41: 311-349.

7. Morand S (1988) Contribution a letude dun systeme hotes-parasites: nematodes associes a quelques mollusques terrestres. These doctorate, Universite de Rennes, pp. 265.

8. Gleich JG, Gilbert FF, Kutscha NP (1977) Nematodes in terrestrial gastropods from central Maine. See comment in PubMed Commons below J Wildl Dis 13: 43-46.

9. Charwat SM1, Davies KA (1999) Laboratory screening of nematodes isolated from south australia for potential as biocontrol agents of helicid snails See comment in PubMed Commons below J Invertebr Pathol 74: 55-61.

10. Cabaret J, Morand S, Aubert C, Yvore P (1988) Snail Farming: A Survey of Breeding Management, Hygiene and Parasitism Of The Garden Snail, Helix Aspersa MÃller. J Mollus Stud 54: 209-214.

11. Wilson MJ, Hughes LA, Hamacher GM, Glen DM (2000) Effects of Phasmarhabditis hermaphrodita on non-target molluscs. Pest Manag Sci 56: 711-716.

12. Baker G H (2002) Molluscs as Crop Pests. Wallingford, UK, CAB International.

13. Floyd R, Abebe E, Papert A, Blaxter M (2002) Molecular barcodes for soil nematode identification. See comment in PubMed Commons below Mol Ecol 11: 839-850.

14. Dorris M, De Ley P, Blaxter ML (1999) Molecular analysis of nematode diversity and the evolution of parasitism. See comment in PubMed Commons below Parasitol Today 15: 188-193.

15. Kiontke K, Barrière A, Kolotuev I, Podbilewicz B, Sommer R, et al. (2007) Trends, stasis, and drift in the evolution of nematode vulva development. See comment in PubMed Commons below Curr Biol 17: 1925-1937.

16. Tamura K, Dudley J, Nei M, Kumar S (2007) MEGA4: Molecular Evolutionary Genetics Analysis (MEGA) software version 4.0. See comment in PubMed Commons below Mol Biol Evol 24: 1596-1599.

17. Altschul SF, Madden TL, Schaffer AA, Zhang J, Zhang Z, et al. (1997) Gapped BLAST and PSIBLAST: a new generation of protein database search programs. Nucleic Acids Res 25: 3389-3402.

18. Thompson JD, Gibson TJ, Plewniak F, Jeanmougin F, Higgins DG (1997) The ClustalX windows interface: flexible strategies for multiple sequence alignment aided by quality analysis tools. Nucleic Acids Res 25: 4876-4882.

19. Hodda M (2007) Phylum Nematoda. Linnaeus Tercentenary: Progress in Invertebrate Taxonomy. Zootaxa. ZQ, Zhang and WA Shear 1668: 265-293.

20. Nadler SA1, De Ley P, Mundo-Ocampo M, Smythe AB, Patricia Stock S, et al. (2006) Phylogeny of Cephalobina (Nematoda): molecular evidence for recurrent evolution of probolae and incongruence with traditional 
Citation: Wang A, Ash G, Hodda M, Jahromi FG (2015) Molecular Phylogeny Inferred from 18S rRNA Gene Sequences of Nematodes Associated with Cernuella virgata, a Pest Snail in Australia. J Phylogen Evolution Biol 3: 148. doi:10.4172/2329-9002.1000148

Page 10 of 10

classifications. See comment in PubMed Commons below Mol Phylogenet Evol 40: 696-711.

21. De Ley P (1997) The current state of affairs in identification and diagnosis of the genera of the family Cephalobidae (Nematoda: Rhabditida). Meded Fac Landbouwkd Toegep Biol Wet Univ Gent 62: 657-673.

22. Lieven A (2002) The sister group of the Diplogasterina (Nematoda). Russ J Nematol 10: 127-137.

23. Goodey JB (1963) Speculations on the identity of the parts of the tylenchid spear. Nematologica 9: 468-70.

24. Baldwin JG, De Ley IT, Mundo-Ocampo M, De Ley P, Nadler SA, et al. (2001) Acromoldavicus mojavicus n sp (Nematoda: Cephaloboidea) from the Mojave Desert, California. Nematology 3: 343-353

25. Th $\tilde{\odot}$ odoridÃ "s J (1965) Histoire de la Biologie. P.U.F, Paris.

26. Stock SP, Hunt DJ (2005) Morphology and systematics of nematodes used in biocontrol. In: Grewal, PS, Ehlers RU, Shapiro-Ilan DI (Eds.), Nematodes as Biological Agents. CABI Publishing, Wallingford, UK, pp. 3-43.

27. Kaya HK, Gaugler R (1993) Entomopathogenic nematodes. Ann Rev Entomol 38: 181-206.

28. Liu J, Poinar GO Jr, Berry RE (2000) Control of insect pests with entomopathogenic nematodes: the impact of molecular biology and phylogenetic reconstruction. See comment in PubMed Commons below Annu Rev Entomol 45: 287-306.

29. Adams BJ, Fodor A, Koppenhofer HS, Stackebrandt E, Stock SP, et al. (2006) Biodiversity and systematics of nematode-bacterium entomopathogens. Biol Control. 37: 32-49.
30. Rae R1, Verdun C, Grewal PS, Robertson JF, Wilson MJ (2007) Biological control of terrestrial molluscs using Phasmarhabditis hermaphrodita-progress and prospects. See comment in PubMed Commons below Pest Manag Sci 63: 1153-1164.

31. Wilson M J, Glen D M, George SK (1993) The rhabditid nematode Phasmarhabditis hermaphrodita as a potential biological control agent for slugs. Biocontrol Sci Techn 3: 503 - 511.

32. Blaxter ML (2003) Nematoda: genes, genomes and the evolution of parasitism. See comment in PubMed Commons below Adv Parasitol 54: 101-195.

33. Kiontke K, Gavin NP, Raynes Y, Roehrig C, Piano F, et al. (2004) Caenorhabditis phylogeny predicts convergence of hermaphroditism and extensive intron loss. See comment in PubMed Commons below Proc Natl Acad Sci U S A 101: 9003-9008.

34. Mitreva M, Smant G, Helder J (2009) Role of horizontal gene transfer in the evolution of plant parasitism among nematodes. See comment in PubMed Commons below Methods Mol Biol 532: 517-535.

35. Scholl EH, Thorne JL, McCarter JP, Bird DM (2003) Horizontally transferred genes in plant-parasitic nematodes: a high-throughput genomic approach. See comment in PubMed Commons below Genome Biol 4: R39.

36. Wang J, Kim SK (2003) Global analysis of dauer gene expression in Caenorhabditis elegans. See comment in PubMed Commons below Development 130: 1621-1634. 